\title{
Seedling development and growth of white clover, caucasian clover and perennial ryegrass grown in field and controlled environments
}

\author{
A.D. BLACK, D.J. MOOT and R.J. LUCAS \\ Field Service Centre, P.O. Box 84, Lincoln University, Canterbury \\ blacka1@lincoln.ac.nz
}

\begin{abstract}
Autumn sowing on 4 February (SD1) and 31 March (SD2) 2000 was used to compare the establishment success of white and caucasian clovers sown with 0,3 , 6 or $12 \mathrm{~kg} \mathrm{seed} / \mathrm{ha}$ of perennial ryegrass. Total dry matter (DM) production from sowing to 3 October 2000 averaged 5770 and $3470 \mathrm{~kg} \mathrm{DM} /$ ha for the two sowing dates, respectively. Clover species did not affect herbage production in monocultures which averaged $2610 \mathrm{~kg}$ $\mathrm{DM} / \mathrm{ha}$. The total DM increase from the addition of ryegrass was 87,109 and $114 \%$ for 3,6 and $12 \mathrm{~kg} / \mathrm{ha}$, respectively. On 3 October 2000, white clover content averaged $15 \%$ when sown with $3-12 \mathrm{~kg} / \mathrm{ha}$ ryegrass on SD1 but less than 2\% for SD2. Caucasian clover never exceeded $9 \%$ in either sowing and weed content was $\leq 2 \%$ when ryegrass was included for SD1 but $18 \%$ for SD2.
\end{abstract}

A complimentary controlled environment study examined seedling development and growth of the three species. For each species the leaf appearance interval (phyllochron) in days differed across temperatures but was constant in thermal time at $94^{\circ} \mathrm{Cd}$ for white clover, $109^{\circ} \mathrm{Cd}$ for caucasian clover and $101^{\circ} \mathrm{Cd}$ for ryegrass. Axillary leaves and tillers of ryegrass first appeared after $375^{\circ} \mathrm{Cd}$ compared with $439^{\circ} \mathrm{Cd}$ for axillary leaves of white clover and $532^{\circ} \mathrm{Cd}$ for stolon initials. No secondary leaf development or rhizome initiation was detected in caucasian clover up to $774^{\circ} \mathrm{Cd}$. At this time ryegrass seedling shoots were $635 \mathrm{mg} /$ plant compared with 167 and $184 \mathrm{mg} / \mathrm{plant}$ for white and caucasian clovers, respectively. Thus, the success of ryegrass seedlings during autumn pasture establishment was explained by its high relative growth rate, and rapid onset of axillary leaf and tiller development compared with white and particularly caucasian clovers. Successful caucasian clover establishment is most likely to occur in the absence of either ryegrass or white clover.

Keywords: axillary shoots, Lolium perenne, pasture establishment, phyllochron, sowing date, sowing rate, thermal time, Trifolium ambiguum, Trifolium repens

\section{Introduction}

Recent studies into white (Trifolium repens L.) (Brock \& Hay 2001) and caucasian (Trifolium ambiguum M. Bieb) clover (Widdup et al. 1998) establishment have indicated a need to identify parameters which may explain differences in species establishment success in sown pastures. This information can assist management decisions on time of sowing and compatibility of species within a seed mixture. For example sowing in autumn, when soil temperatures are below $14^{\circ} \mathrm{C}$, or using ryegrass (Lolium perenne L.) sowing rates greater than $10 \mathrm{~kg} / \mathrm{ha}$ may optimise ryegrass establishment at the expense of slower establishing species (Cullen 1958; Hurst et al. 2000; Moot et al. 2000). However, repeatable criteria to define 'slower establishment' are required to assist decision-making.

Moot et al. (2000) used thermal time (Arnold \& Monteith 1974) to quantify differences in germination and emergence requirements of common New Zealand pasture species. The advantage of this approach is that it provides easily transferable and repeatable values that are independent of location and season, and can be used directly in field measurements. However, Moot et al. (2000) indicated that additional seedling parameters were required for the prediction of species performance in a mixture. Specifically, leaf appearance rate (phyllochron) and the timing of axillary shoot development (branch or tiller structures) are two major seedling components that affect canopy expansion, and consequently light interception, growth and therefore seedling competitiveness. The phyllochron and development of axillary shoots may also be quantified in thermal time. Together, these physiological parameters provide a basis for understanding seedling competitiveness and ultimately could be used to identify genetic diversity within populations that can be used as selection criteria in plant breeding.

Thus, the initial objective of this research was to compare the 6-8 month establishment phase (Thom et al. 1987) of white and caucasian clover based pastures sown in the field with different sowing rates of ryegrass on two autumn sowing dates. The second objective was to relate establishment success of each species to differences in growth (leaf area, seedling dry weight) and development (leaf appearance rates, axillary shoot development) between species. This was done through a complimentary series of controlled environment experiments.

\section{Materials and methods}

\section{Field experiment}

A split-plot factorial design experiment was sown in 
two replicates with 4 February and 31 March 2000 sowing dates as main plots. Sub-plots were 'Grasslands Demand' white clover ( $2 \mathrm{~kg} / \mathrm{ha}$ ) and 'Endura' caucasian clover $(8 \mathrm{~kg} / \mathrm{ha}$ ) with $0,3,6$ or $12 \mathrm{~kg} / \mathrm{ha}$ of 'Nui' perennial ryegrass infected with the AR1 strain Neotyphodium lolii. Sub-plots were 2.1 x $6.0 \mathrm{~m}$ drilled with an Øyjoord cone seeder at $150 \mathrm{~mm}$ row spacing and a target depth of 15 $\mathrm{mm}$.

Prior to sowing, the experimental area was cultivated using conventional methods and fertilised with sulphur superphosphate ( $8 \% \mathrm{P}, 19 \% \mathrm{~S})$ at 250 $\mathrm{kg} / \mathrm{ha}$. Before each sowing, 'Buster' (glufosinateammonium) was sprayed (600g ai/ha) to kill weeds. White and caucasian clover seeds were lime-coated and inoculated with Rhizobium trifolii strains CC275e and ICC148, respectively. Between December 1999 and March 2000, plots received $120 \mathrm{~mm}$ of irrigation water based on a soil water budget to prevent a deficit of $25 \mathrm{~mm}$ in the top $0.50 \mathrm{~m}$ of soil.

Directly after sowing, soil temperature probes were placed in two plots at a depth of $15 \mathrm{~mm}$. Air temperature was recorded from a single probe placed in a Stevenson screen adjacent to the experimental area. Temperatures were recorded every 5 minutes and integrated every hour with a DT100 data logger to determine daily mean temperatures (Figure 1).

Young sheep first grazed plots when seedlings could not be removed by pulling with the finger and thumb. Thus, 4 February sown plots were first grazed 57 days after sowing (DAS) on 2 April and 31 March sown plots on 30 June (91 DAS). Plots were subsequently grazed at 6-8 week intervals when 1500 to $2000 \mathrm{~kg} / \mathrm{ha}$ of dry matter (DM) had accumulated.

Figure 1 Mean 7 day screen (-) and $15 \mathrm{~mm}$ soil (-) temperatures, and sowing dates $(\downarrow)$ for the field experiment sown at Lincoln University in 2000.

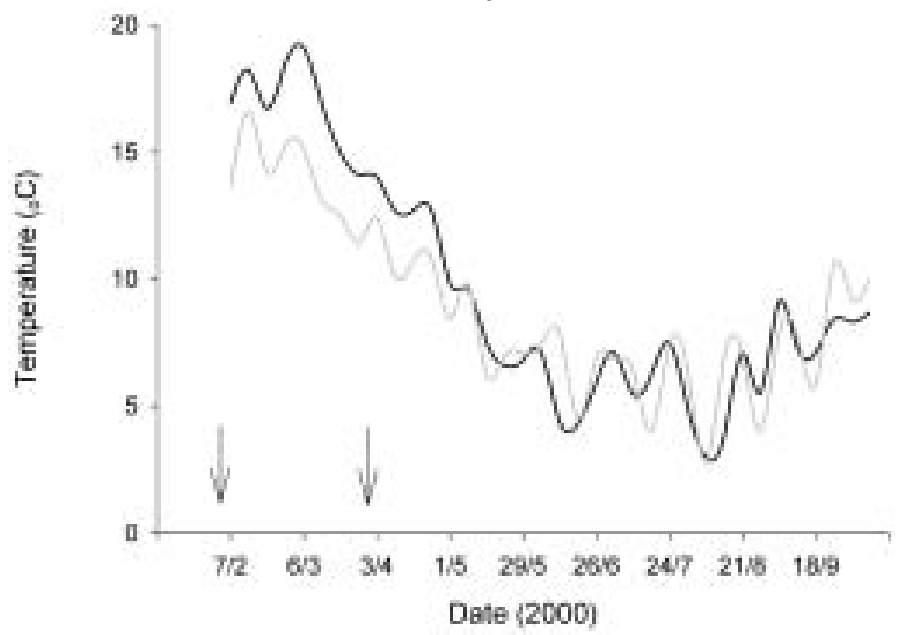

\section{Measurements}

Plant population for each species was determined at the time of first grazing from plant counts within two randomly placed $0.2 \mathrm{~m}^{2}$ quadrats in each sub-plot. Also at this time, the mean seedling shoot weight, and the number of leaves emerged on individual plants were measured from 10 plants per sub-plot harvested at ground level. Leaves were considered to have emerged when the petiole of clovers was first visible and when ryegrass leaves had formed a collar (Hsu \& Nelson 1986).

Pasture herbage DM production was determined from pre- and post-grazing herbage cuts to $30 \mathrm{~mm}$ above ground level from one randomly placed $0.2 \mathrm{~m}^{2}$ quadrat in each sub-plot. Herbage from the final harvest on 3 October 2000 was dissected to determine botanical composition.

\section{Laboratory experiment}

In controlled environment cabinets, three replicates of three species were grown from seed sown at a depth of $10 \mathrm{~mm}$ in 4 litre plastic pots at $7 / 4,13 / 5,18 / 10$ or $23 /$ $15^{\circ} \mathrm{C}$ with $8 \mathrm{~h}$ day $/ 8 \mathrm{~h}$ night, and $4 \mathrm{~h}$ transitions between. The growing medium was bark and pumice $(4: 1$ by volume) below a 20-mm layer of loam and peat (1:1) and amended with $1 \mathrm{~g} / \mathrm{l}$ of Osmocote Plus (15\% N, 5\% P, $11 \% \mathrm{~K})$, trace elements and $1 \mathrm{~g} / \mathrm{l}$ of dolomite lime $(11 \%$ $\mathrm{Mg}, 24 \% \mathrm{Ca}$ ). Clover seeds were inoculated using the $R$. trifolii strains as described for the field experiment. Light reaching the plant canopies had a photosynthetic photon flux density of $350 \pm 50 \mu \mathrm{mol} / \mathrm{m}^{2} / \mathrm{s}$ and relative humidity was $65 \%$. Pots were watered daily and re-randomised weekly.

Directly after sowing, soil temperature probes (covered with aluminium foil) were placed in two pots, located $10 \mathrm{~mm}$ above the soil surface, to be in close proximity to the seedling apical growing points, the major site of temperature perception by the plant (Peacock 1975). Such placement has been recommended for accurate prediction of leaf appearance rates in crops (Jamieson et al. 1995). Temperatures were recorded every 5 minutes and integrated every hour with a HOBO data logger to determine daily mean temperatures.

\section{Measurements}

The number of emerged leaves on the primary growing point and total number of emerged leaves of 10 plants per pot (390 plants $/ \mathrm{m}^{2}$ ) were counted daily until a final destructive harvest of all plants 
was made when individual caucasian clover plants had produced five leaves (up to $774^{\circ} \mathrm{Cd}$ ). The initiation of axillary leaves and branches (stolon or rhizome initials) or tiller structures, which emerged in the axils of primary leaves, was also recorded. For example, stolon initiation was defined as when $50 \%$ of plants had formed a stolon initial from the primary crown.

Leaf area of individual plants was measured for each species using a LI-COR model LI-3100 leaf area meter. Shoot and root dry weights were also determined and shoot relative growth rate $(\mathrm{RGR}=\mathrm{mg} / \mathrm{mg} / \mathrm{d})$ was calculated from the logarithm of individual seed weight and mean seedling shoot weight of individual plants for each species. The 1000-seed weights (uncoated) were measured as $0.63 \mathrm{~g}$ for white clover, $2.20 \mathrm{~g}$ for caucasian clover and $2.00 \mathrm{~g}$ for ryegrass.

\section{Data analysis}

Leaf appearance interval (days/leaf) was calculated from cumulative primary leaf number over DAS. The base temperature $\left(\mathrm{T}_{\mathrm{b}}\right)$ and thermal time $(\mathrm{Tt})$ requirements for the phyllochron and the initiation of axillary leaves, branch or tiller structures were defined using a linear model of leaf development rate and mean temperature as described by Angus et al. (1981) and used by Moot et al. (2000). Least squares regression analysis was used for the positive linear portion of the line where:

Rate $=b_{o}+b_{1} x$.

The regression coefficients can then be related to $T_{b}$ and $\mathrm{Tt}$ (Angus et al. 1981) as:

$\mathrm{T}_{\mathrm{b}}=-\mathrm{b}_{\mathrm{o}} / \mathrm{b}_{1}$

and

$\mathrm{Tt}=1 / \mathrm{b}_{1}$.

Treatment differences were identified and standard error of means (SEM) calculated using analysis of variance by the GENSTAT 5 Release 4.1 statistical package.

\section{Results \\ Field experiment}

At first harvest for the 4 February sowing, total DM was not affected by clover species but increased from 80 to $1460 \mathrm{~kg} \mathrm{DM} /$ ha with increased ryegrass sowing rate (Table 1). Similarly for the 31 March sowing clover species did not affect yield at first harvest but ryegrass sowing rate did.

The total DM production from sowing to 3 October 2000 was similar between clover species but affected by the interaction of sowing date and sowing rate (Table 1). For the February sowing, total DM increased from $3490 \mathrm{~kg} \mathrm{DM} / \mathrm{ha}$ in clover monocultures up to $6870 \mathrm{~kg} \mathrm{DM} / \mathrm{ha}$ with $6 \mathrm{~kg} / \mathrm{ha}$ of ryegrass. For the March sowing, total DM was $1720 \mathrm{~kg} \mathrm{DM} / \mathrm{ha}$ for pure clover but continued to increase with increased ryegrass sowing rate up to $4350 \mathrm{~kg} \mathrm{DM} / \mathrm{ha}$ for $12 \mathrm{~kg} / \mathrm{ha}$.

In October the botanical composition of the 8-month old pastures from sowing in February showed more clover and fewer weeds than the 6-month-old pastures (sown in March) regardless of ryegrass sowing rate (Figure 2). Clover and weed contents were highest in monocultures of each clover species but decreased exponentially as ryegrass sowing rate increased. For the February sowing, the addition of ryegrass reduced the white clover content from $25 \%$ at $3 \mathrm{~kg} / \mathrm{ha}$ to $9 \%$ at $12 \mathrm{~kg} /$ ha, but weed content was always $\leq 2 \%$ when ryegrass was included. In contrast February sown caucasian clover plots had $91 \%$ weeds (hawksbeard (Crepis capillaris), wireweed (Polygonum aviculare), annual poa (Роа аппиа)) and only 9\% clover in the monoculture and $\leq 2 \%$ clover when ryegrass was included. For the March sowing neither clover was more than $3 \%$ of the composition when ryegrass was included and the weed content was $15-20 \%$. The predominant winter annual weeds were chickweed (Stellaria media L.) and annual poa.

Examination of individual seedlings at the first harvest of each sowing date showed clover plant population was similar between species but declined

Table 1 Total dry matter (DM) production of white (WC) and caucasian (CC) clover based pastures at the first harvest date and up to 3 October 2000 after sowing on 4 February (SD1) and 31 March (SD2) 2000 with different ryegrass sowing rates.

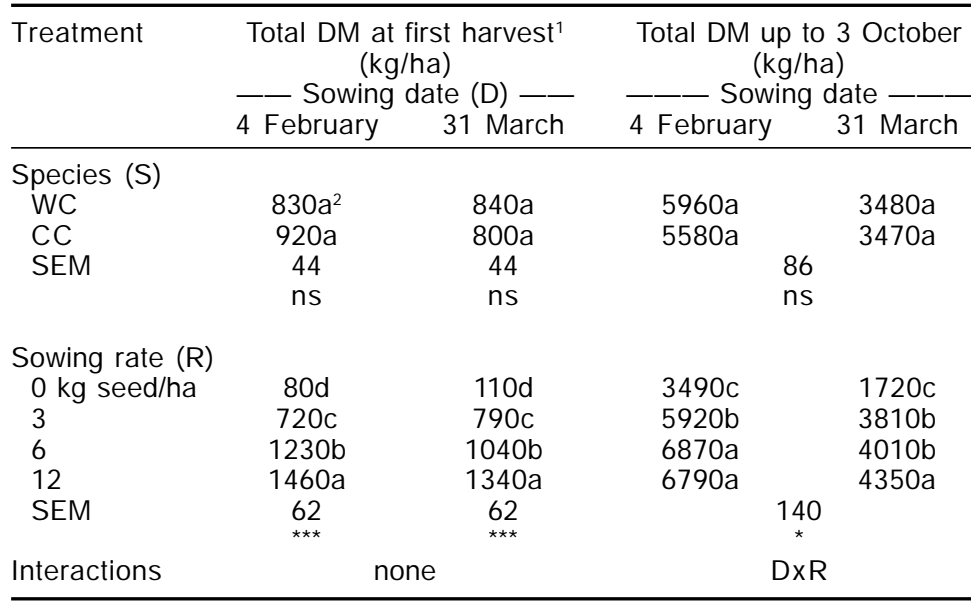

$*, * *, * * * \alpha=0.05,0.01$ and 0.001 , respectively. $\mathrm{ns}=$ not significant.

${ }^{1}$ First harvest dates: SD1 = 2 April (57 DAS), SD2 $=30 \mathrm{~J}$ une (91 DAS).

2 Means in a column for each main effect, with a letter in common are not significantly different $\alpha=0.05$. 
Figure 2 Percentage of ryegrass ( $\square$ ), clover (O) and weeds $(\Delta)$ on 3 October 2000 from pastures sown on 4 February $(A)$ and 31 March (B) with white (open symbols) or caucasian (closed symbols) clovers and perennial ryegrass. Error bars represent the maximum standard error of means.

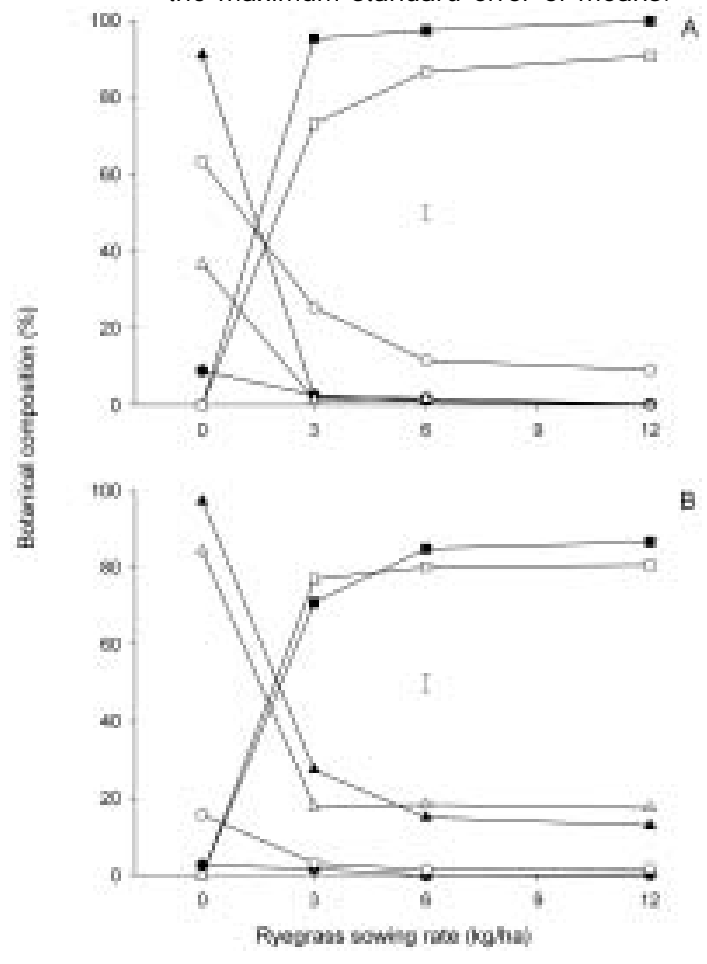

from 77 (February) to 39 plants $/ \mathrm{m}^{2}$ at the March sowing date and from 66 to 46 plants $/ \mathrm{m}^{2}$ as ryegrass sowing rate increased from 0 to $12 \mathrm{~kg} / \mathrm{ha}$ (Table 2). In contrast, ryegrass plant population was unaffected by clover species or sowing date but increased from 79 to 286 plants $/ \mathrm{m}^{2}$ across sowing rates.

The mean shoot dry weight of clover species was 31 $\mathrm{mg} /$ plant compared with an average of $511 \mathrm{mg} /$ plant for ryegrass (Table 2). Clover sown in February averaged $48 \mathrm{mg} /$ plant compared with only $14 \mathrm{mg} /$ plant when sown in March. Also, February sown ryegrass plants averaged nearly $700 \mathrm{mg} /$ plant but this was halved by the March sowing. The shoot weight of clover plants decreased from 36 to $26 \mathrm{mg} /$ plant as ryegrass sowing rate increased from 3 to $12 \mathrm{~kg} / \mathrm{ha}$.

The number of leaves per clover plant was influenced by the interaction of species and sowing date (Table 2). Specifically, the number of leaves on white clover decreased from 7.6 to 4.8 between dates but only from 4.7 to 3.4 for caucasian clover. For ryegrass the number of leaves was about 14 for all treatments being the mean of 17 from February and 10 from March sowing. From these results and 15-mm soil temperatures (Figure 1) an estimate of the phyllochron was obtained by dividing the total accumulated thermal time (above $\mathrm{T}_{\mathrm{b}}$ of $0^{\circ} \mathrm{C}$ ) by the number of leaves per plant. These were $106^{\circ} \mathrm{Cd}$ for white clover, $160^{\circ} \mathrm{Cd}$ for caucasian clover and $50^{\circ} \mathrm{Cd}$ for ryegrass. However, these results were confounded by secondary branching in white clover and tillering in ryegrass. This necessitated the controlled environment study to accurately define morphological development.

\section{Laboratory experiment}

At each temperature, the number of leaves on the primary growing point increased linearly with DAS in all species (Figure 3). Axillary leaves were initiated in ryegrass and white clover when the third and fourth primary leaves appeared, respectively. The development of secondary

Figure 3 Number of leaves emerged from the apical (linear relationship) and axillary (exponential relationship) growing points against days after sowing for perennial ryegrass (A), white (B) and caucasian (C) clovers at mean temperatures of $6.5(\mathbf{\bullet})$, $10(0), 15(\square)$ or $20^{\circ} \mathrm{C}(\square)$. Arrows indicate the initiation of secondary ryegrass tillers and white clover stolons. Error bars represent standard error of means for final total leaf number across all temperatures.
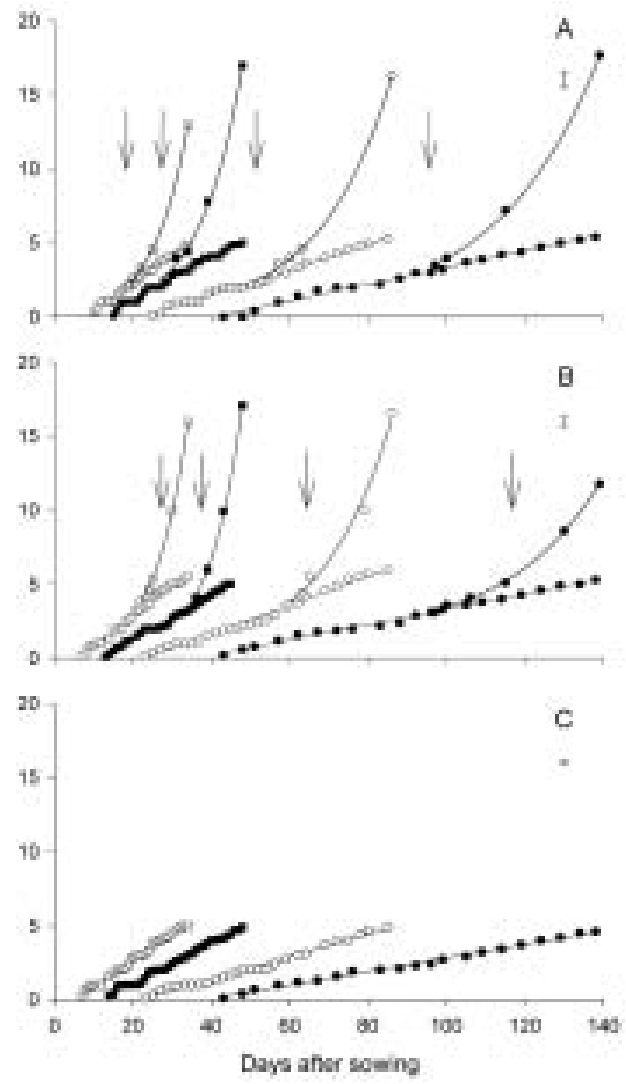
Table 2 Seedling characteristics of white (WC) and caucasian (CC) clovers and ryegrass at the first harvest date $^{1}$ after sowing on 4 February (SD1) and 31 March (SD2) 2000 with different ryegrass sowing rates.

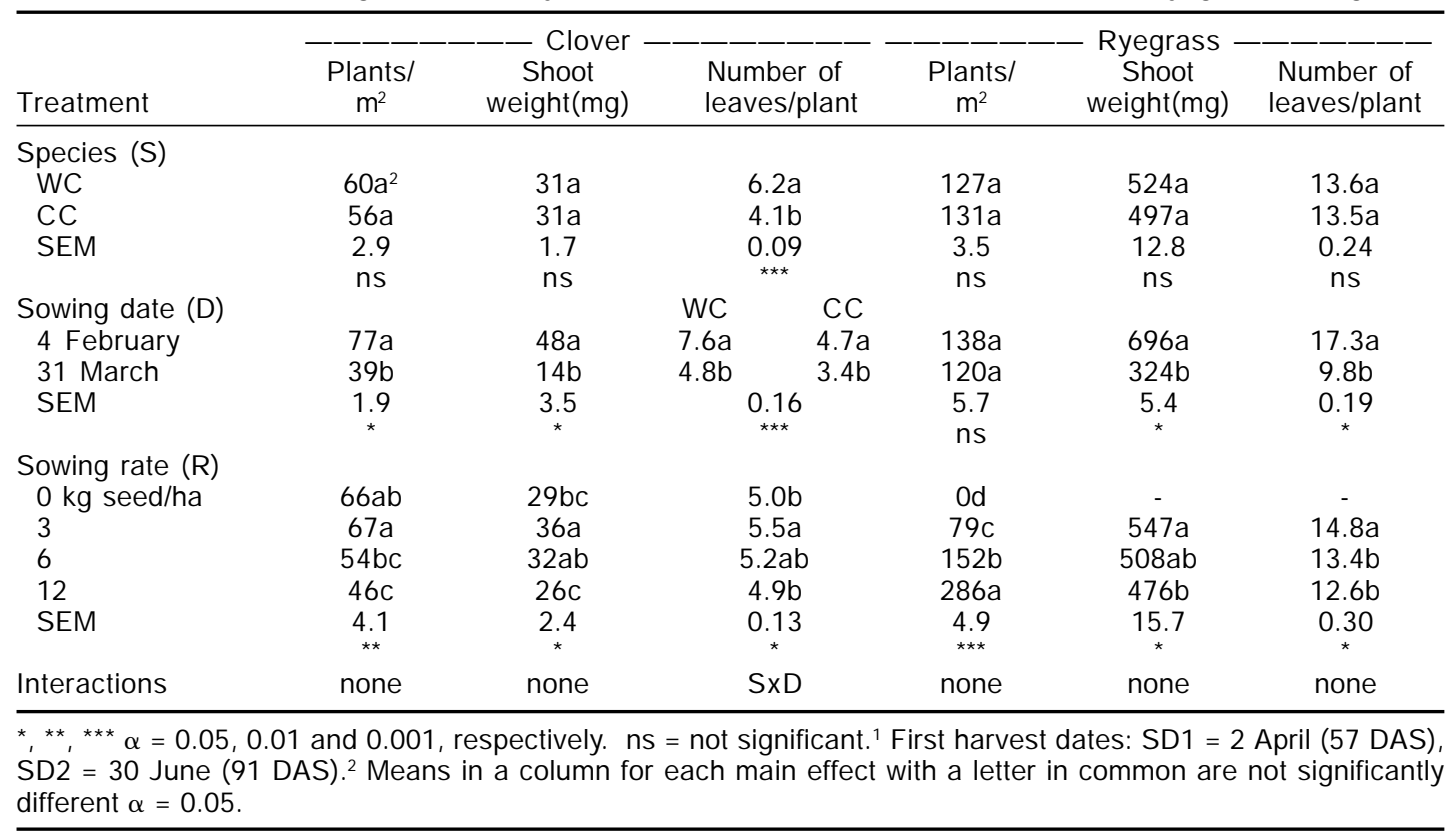

Table 3 Growth and development of white clover (WC), caucasian clover (CC) and ryegrass (PR) seedlings grown in controlled environment conditions at different temperatures.

\begin{tabular}{|c|c|c|c|c|c|c|c|}
\hline Treatment & $\begin{array}{c}\text { Number of } \\
\text { leaves/ } \\
\text { plant }\end{array}$ & $\begin{array}{c}\text { Number of } \\
{ }^{1} \mathrm{Br} \text {. or }{ }^{2} \mathrm{Ti} . / \\
\text { plant }\end{array}$ & $\begin{array}{c}\text { Leaf area/ } \\
\text { plant } \\
\left(\mathrm{cm}^{2}\right)\end{array}$ & $\begin{array}{l}\text { Shoot } \\
\text { weight } \\
\text { (mg) }\end{array}$ & $\begin{array}{l}\text { Root } \\
\text { weight } \\
\text { (mg) }\end{array}$ & $\begin{array}{c}\text { Shoot } \\
{ }^{3} \mathrm{R} G R \\
\text { (mg/mg/d) }\end{array}$ & $\begin{array}{l}\text { Root/ } \\
\text { shoot } \\
\text { ratio }\end{array}$ \\
\hline \multicolumn{8}{|l|}{ Species (S) } \\
\hline WC & $15.6 a^{4}$ & $2.5 \mathrm{~b}$ & $24 b$ & $167 \mathrm{~b}$ & $65 b$ & $0.042 a$ & $0.39 \mathrm{~b}$ \\
\hline $\mathrm{CC}$ & $5.1 \mathrm{~b}$ & $0 \mathrm{c}$ & $24 b$ & $184 \mathrm{~b}$ & $92 \mathrm{~b}$ & $0.033 \mathrm{~b}$ & $0.50 a$ \\
\hline$P R$ & $16.0 \mathrm{a}$ & $7.7 a$ & $86 a$ & $635 a$ & $333 a$ & $0.042 a$ & $0.54 a$ \\
\hline SEM & 0.32 & 0.14 & 2.0 & 8.3 & 12.1 & 0.0002 & 0.020 \\
\hline & $*$ wa & *wa & $* * *$ & 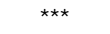 & *w* & *承 & **a \\
\hline \multicolumn{8}{|c|}{ Temperature $(\mathrm{T})$} \\
\hline $6.5^{\circ} \mathrm{C}$ & $11.4 \mathrm{~b}$ & $3.6 a$ & $39 b$ & $303 b$ & $120 \mathrm{~b}$ & $0.016 d$ & $0.41 \mathrm{~b}$ \\
\hline 10 & $12.7 a b$ & $3.7 a$ & $54 a$ & $459 a$ & $222 a$ & $0.028 \mathrm{c}$ & $0.49 a b$ \\
\hline 15 & $13.4 a$ & $3.5 a$ & $46 a b$ & $320 \mathrm{~b}$ & $201 a$ & $0.048 b$ & $0.56 a$ \\
\hline 20 & $11.3 \mathrm{~b}$ & $2.9 \mathrm{~b}$ & $41 \mathrm{~b}$ & $233 c$ & $110 \mathrm{~b}$ & $0.064 a$ & $0.45 b$ \\
\hline \multirow{2}{*}{ SEM } & 0.43 & 0.14 & 2.5 & 9.2 & 11.3 & 0.0003 & 0.026 \\
\hline & $*$ & * & * & *w* & $* * *$ & *w* & $*$ \\
\hline Interaction & *ak & ** & ** & *at & ** & *w* & ** \\
\hline
\end{tabular}

$*, * *, * * * \alpha=0.05,0.01$ and 0.001 , respectively.

${ }^{1} \mathrm{Br} .=$ branches; ${ }^{2} \mathrm{Ti} .=$ tillers; ${ }^{3} \mathrm{R} \mathrm{GR}=$ relative growth rate.

${ }^{4}$ Means in a column for each main effect with a letter in common are not significantly different $\alpha=0.05$.

ryegrass tillers and white clover stolons led to an exponential increase in the total number of leaves with DAS. Caucasian clover had not initiated axillary leaves or rhizomes before the fifth primary leaf had appeared which meant at harvest (up to $774^{\circ} \mathrm{Cd}$ ) the total number of leaves produced was only five compared with 16 for the other two species (Table 3).

The leaf appearance interval (days/leaf) from the primary growing point was greater than 18 days at $6.5^{\circ} \mathrm{C}$ for each species but decreased exponentially to be about 5 days as temperature increased to a mean of $19^{\circ} \mathrm{C}$ (Figure 4A). However, leaf appearance rate (leaves/day) was a linear function $\left(\mathrm{R}^{2} \geq 99 \%\right)$ of mean temperature (Figure 4B) which enabled $T_{b}$ to be estimated at about $1^{\circ} \mathrm{C}$ for all species. Linear relationships $\left(\mathrm{R}^{2} \geq 98 \%\right)$ between axillary leaf and stolon/tiller initiation rates and temperature were also found in white clover and ryegrass, and an average $\mathrm{T}_{\mathrm{b}}$ of $2.4^{\circ} \mathrm{C}$ was calculated. 
Figure 4 Leaf appearance interval (days/leaf) (A) and leaf appearance rate (leaves/day) (B) from the apical growing point of caucasian clover (•), white clover (O) and perennial ryegrass $(\mathbf{\Lambda})$ against temperatures.

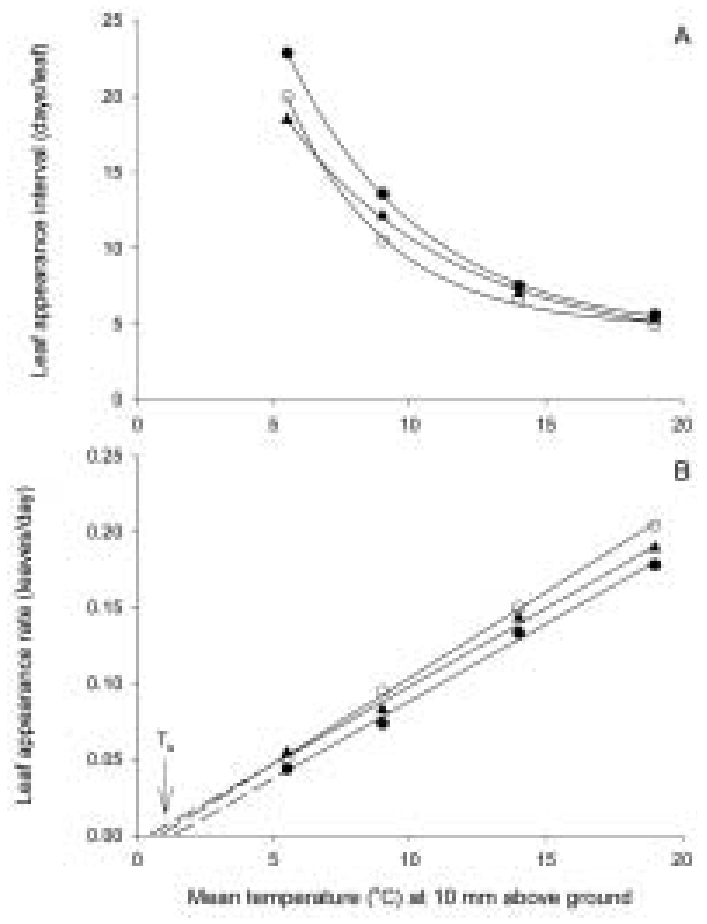

To enable direct comparison of the phyllochron and timing of axillary leaf and stolon/tiller initiation between species, additional regression analyses were performed with the $\mathrm{T}_{\mathrm{b}}$ set at $0^{\circ} \mathrm{C}$ (Moot et al. 2000). This enabled the phyllochron to be estimated for white $\left(94^{\circ} \mathrm{Cd}\right)$ and caucasian $\left(109^{\circ} \mathrm{Cd}\right)$ clovers and perennial ryegrass $\left(101^{\circ} \mathrm{Cd}\right)\left(\mathrm{SEM}=0.5^{\circ} \mathrm{Cd}\right)$. Axillary leaves and tillers of ryegrass initially appeared after $375^{\circ} \mathrm{Cd}$ compared with $439^{\circ} \mathrm{Cd}$ for axillary leaves of white clover and $532^{\circ} \mathrm{Cd}$ for stolon initials $\left(\mathrm{SEM}=2 \cdot 2^{\circ} \mathrm{Cd}\right)$. No secondary leaf development or rhizome initiation was detected in caucasian clover before $774^{\circ} \mathrm{Cd}$.

Main effects of species and temperature and their interaction were significant for all seedling growth parameters measured at harvest (Table 3). In general, most seedling characteristics (except shoot RGR) were highest at 10 and $15^{\circ} \mathrm{C}$. The leaf area of clover species was similar at $24 \mathrm{~cm}^{2} /$ plant compared with $86 \mathrm{~cm}^{2} /$ plant for ryegrass. This corresponded with average clover shoot weights of $176 \mathrm{mg} / \mathrm{plant}$ compared with $635 \mathrm{mg} /$ plant for ryegrass, but shoot RGR was highest for white clover and ryegrass at $0.042 \mathrm{mg} / \mathrm{mg} / \mathrm{d}$ compared with $0.033 \mathrm{mg} / \mathrm{mg} / \mathrm{d}$ for caucasian clover. In contrast, root/ shoot ratios of caucasian clover and ryegrass were similar at 0.52 compared with 0.39 for white clover.

\section{Discussion}

The establishment success of individual species dictates the initial composition and ultimately the quality and persistence of perennial pastures. In this study, all treatments sown on 4 February had produced about $2 \mathrm{t}$ $\mathrm{DM} /$ ha more than corresponding treatments sown on 31 March when plots were harvested in the following spring (Table 1). This production difference represents the advantage gained from the greater accumulation of thermal time for the 4 February sowing date. This allowed the development of more leaves and as a consequence canopy closure was earlier and therefore the amount of light interception was greater for photosynthesis and growth. On this basis rapid leaf appearance and early canopy closure are favourable attributes leading to greater DM production. Indeed, this combination is considered desirable in annual crop production to maximise biological and grain yields and to suppress weeds. However, in pastures these same attributes can confer a significant competitive advantage to one species to the detriment of others.

The botanical composition (Figure 2) and seedling characteristics (Table 2) of the pastures sown in this study highlight this dilemma. The dominance of ryegrass in the composition has been at the expense of clover establishment. Only white clover sown on 4 February reached adequate levels when mixed with ryegrass. The impact of rapid leaf development and heavier seedling weights of ryegrass (Table 2) was accentuated by the late sowing, with no clover treatment producing over $20 \%$ of the subsequent spring composition, even in monocultures. This result is consistent with Moot et al. (2000) who recommended white clover based pastures be sown when autumn soil temperatures at $20 \mathrm{~mm}$ soil depth are at least $14^{\circ} \mathrm{C}$. The substitution of clover with winter annual weeds in pastures sown on 31 March, when air and soil temperatures were declining rapidly supports this conclusion. Thus, white clover establishment was successful from the February sowing with the inclusion of 3 to $12 \mathrm{~kg} / \mathrm{ha}$ of ryegrass and all combinations minimised weed ingress to less than $2 \%$.

In contrast, none of the treatments used in this study resulted in acceptable establishment of caucasian clover. Indeed, even when sown on 4 February, when soil temperatures were above $16^{\circ} \mathrm{C}$, and with no ryegrass only $9 \%$ of the botanical composition of the monocultures on 3 October was caucasian clover, the remainder was summer and winter annual weeds. The lack of competitive ability of caucasian clover was apparent with the inclusion of ryegrass reducing plant numbers and composition to less than $2 \%$ of the total DM. This low production of caucasian clover occurred despite an adequate population at establishment. It seems unlikely that surviving plants will 'leap' from the ground to dominate the ryegrass in 
later years. Indeed, successful caucasian clover establishment in ryegrass pastures has usually been achieved from spring sowing with temporal separation of the two species (Black et al. 2000; Hurst et al. 2000).

The controlled environment studies offer insight into the lack of competitive ability of caucasian clover. The rate of leaf appearance was slower in days as temperature decreased in all species (Figure 3) but constant in thermal time. Calculation of the phyllochron summarised these individual temperature responses into repeatable coefficients that could be used for all temperatures in the linear range (Figure 4). This was consistent with results for many annual crops (Qi et al. 1999) but may not hold for higher temperatures, above a species-specific optimum (Baker \& Reddy 2001).

The phyllochron for caucasian clover $\left(109^{\circ} \mathrm{Cd}\right)$ was longer than for ryegrass $\left(101^{\circ} \mathrm{Cd}\right)$ and white clover $\left(94^{\circ} \mathrm{Cd}\right)$ but this difference is unlikely to have been the main cause of poor establishment. Specifically, the lack of axillary leaf development from the primary crown and rhizome initiation (which ultimately results in secondary crowns) in all treatments up to $774^{\circ} \mathrm{Cd}$ after sowing limits caucasian clover competitiveness. A subsequent controlled environment study (Black unpublished data) has shown axillary leaf initiation for caucasian clover only after about $1000^{\circ} \mathrm{Cd}$. In addition, Buckley (unpublished data) has shown rhizome initiation for fieldgrown caucasian clover only after $1400^{\circ} \mathrm{Cd}$. This compares with $375^{\circ} \mathrm{Cd}$ for ryegrass and $440^{\circ} \mathrm{Cd}$ for white clover which also had stolon initials after $530^{\circ} \mathrm{Cd}$ in the present study. Thus, assuming a mean temperature of $10^{\circ} \mathrm{C}$ exponential leaf development begins after 38 days in ryegrass, 44 days in white clover and 100 days in caucasian clover. The consequence of these differences was shown by the number of leaves per plant which was 3 times more in ryegrass and white clover than in caucasian clover up to $774^{\circ} \mathrm{Cd}$ (Table 3).

It remains to be seen if these values are constant among cultivars within species or could be used to select for rapid leaf initiation in slow establishing species. An indication of differences within and between species can be made by re-analysis of published data. For example, Hill \& Luck (1991) compared early leaf development of 'Monaro' caucasian clover and 'Haifa' white clover at different temperatures. However, the impact of thermal time on seedling development was not addressed. Reanalysis of their data indicated phyllochrons of $136^{\circ} \mathrm{Cd}$ for 'Monaro' and $99^{\circ} \mathrm{Cd}$ for 'Haifa' which were similar to the values calculated for these species in the present study.

Despite the thermal time differences the leaf area and shoot dry weight of white and caucasian clovers were not different (Table 3). This result is an artefact of the timing of harvest at a maximum of $774^{\circ} \mathrm{Cd}$. During the additional $230^{\circ} \mathrm{Cd}$ caucasian clover would require to initiate axillary leaves, white clover would be producing leaves at an exponential rate. Under these circumstances even white clover would appear to be too competitive to enable successful establishment of caucasian clover. Again, selection for greater shoot production, even at the expense of root production (Table 3) may assist caucasian clover establishment. Agronomically, spring sowing of caucasian clover is recommended to minimise the interval in days between sowing and exponential leaf production.

\section{Conclusions}

This study has provided quantifiable explanations for differences in establishment success observed between white clover, caucasian clover and perennial ryegrass.

\section{Specific conclusions were:}

1. The relative competitiveness of seedlings of these three pasture species was attributed to their relative growth rate and rate of leaf production in response to accumulated thermal time. In particular, the thermal time required to initiate branching (tillers, stolons, rhizomes, crown shoots) was the most influential parameter controlling the number of leaves produced and consequently canopy development for light interception and seedling growth.

2. White clover establishment with perennial ryegrass was only successful from the 4 February sowing when soil temperature was above $16^{\circ} \mathrm{C}$ and when ryegrass seeding rate was 3 to $12 \mathrm{~kg} / \mathrm{ha}$.

3. Caucasian clover seedlings had a phyllochron of $109^{\circ} \mathrm{Cd}$ which was similar to the other species. However, it did not produce axillary buds up to $774^{\circ} \mathrm{Cd}$ after sowing. This result explains the low establishment success of autumn sown caucasian clover even when the ryegrass seeding rate was restricted to $3 \mathrm{~kg} / \mathrm{ha}$ and soil temperature was above $16^{\circ} \mathrm{C}$ at sowing in February.

\section{ACKNOWLEDGMENTS}

The C. Alma Baker, Struthers and Pukehou Poutu Trusts for providing A.D. Black with post-graduate scholarships. Field Service Centre technical staff for preparation and grazing for the field experiment, Dr Keith Pollock for assistance with monitoring temperatures, Stuart Larson for assistance with the controlled environment cabinets, Wrightson Seeds, Pyne Guild Guinness and AgResearch for providing seed.

\section{REFERENCES}

Angus, J.F.; Cunningham, R.B.; Moncur, M.W.; Mackenzie, D.H. 1981. Phasic development in field crops. 1. Thermal response in the seedling phase. Field Crops Research 3: 365-378. 
Arnold, S.M.; Monteith, J.L. 1974. Plant development and mean temperature in a Teesdale habitat. Journal of Ecology 62: 711-720.

Baker, J.T.; Reddy, V.R. 2001. Temperature effects on phenological development and yield of Muskmelon. Annals of Botany 87: 605-613.

Black, A.D.; Pollock, K.M.; Lucas, R.J.; Amyes, J.M.; Pownall, D.B.; Sedcole, J.R. 2000. Caucasian clover/ ryegrass produced more legume than white clover/ ryegrass pastures in a grazed comparison. Proceedings of the New Zealand Grassland Association 62: 69-74.

Brock, J.L.; Hay, M.J.M. 2001. White clover performance in sown pastures: a biological/ecological perspective. Proceedings of the New Zealand Grassland Association 63: 73-83.

Cullen, N.A. 1958. Pasture establishment studies at Invermay Research Station. Proceedings of the New Zealand Grassland Association 20: 138-147.

Hill, M.J.; Luck. C. 1991. The effect of temperature on germination and seedling growth of temperate perennial pasture legumes. Australian Journal of Agricultural Research 42: 175-189.

Hsu, F.H.; Nelson, C.J. 1986. Planting date effects on seedling development of perennial warm-season forage grasses. II. Seedling growth. Agronomy Journal 78: 38-42.

Hurst, R.G.M.; Black, A.D.; Lucas, R.J.; Moot, D.J. 2000. Sowing strategies for slow-establishing pasture species on a North Otago dairy farm. Proceedings of the New Zealand Grassland Association 62: 129-135. Jamieson, P.D.; Brooking, I.R.; Porter, J.R.; Wilson, D.R. 1995. Prediction of leaf appearance in wheat: a question of temperature. Field Crop Research 41: 35-44.

Moot, D.J.; Scott, W.J.; Roy, A.M.; Nicholls, A.C. 2000. Base temperature and thermal time requirements for germination and emergence of temperate pasture species. New Zealand Journal of Agricultural Research 43: 15-25.

Peacock, J.M. 1975. Temperature and the growth of Lolium perenne. 2. The site of temperature perception. Journal of Applied Ecology 12: 115-123.

Qi, A.; Wheeler, T.R.; Keatinge, J.D.H.; Ellis, R.H.; Summerfield, R.J.; Craufurd, P.Q. 1999. Modelling the effects of temperature on the rates of seedling emergence and leaf appearance in legume cover crops. Experimental Agriculture 35: 327-344.

Thom, E.R.; Thorrold, B.S.; Edgecombe, G.A. 1987. Pasture renovation: the approach. pp. 101-108. In: Pasture renovation for greater productivity. Eds. Pottinger, R.P.; Lane, P.M.S.; East, R. Ruakura Agricultural Centre, MAFTech North, Ministry of Agriculture and Fisheries, Hamilton, New Zealand; Monsanto NZ, Cambridge, New Zealand.

Widdup, K.H.; Knight, T.L.; Waters, C.J. 1998. Genetic variation for rate of establishment in caucasian clover. Proceedings of the New Zealand Grassland Association 60: 213-217. 